\title{
ROTIFERS OF THE UPPER PARANÁ RIVER FLOODPLAIN: ADDITIONS TO THE CHECKLIST
}

\author{
SERAFIM, M. Jr., BONECKER, C. C., ${ }^{2}$ ROSSA, D. C., ${ }^{1}$ \\ LANSAC-TÔHA, F. A. ${ }^{2}$ and COSTA, C. L. ${ }^{3}$ \\ ${ }^{1}$ Universidade Estadual de Maringá, Curso de Pós-graduação em Ecologia de Ambientes Aquáticos Continentais \\ ${ }^{2}$ Nupélia, Curso de Pós-graduação em Ecologia de Ambientes Aquáticos Continentais, \\ Universidade Estadual de Maringá, Av. Colombo, 5790, CEP 87020-900, Maringá, PR, Brazil \\ ${ }^{3}$ Nupélia, Departamento de Biologia da Universidade Estadual de Maringá \\ Correspondence to: Claudia Costa Bonecker, Nupélia, Curso de Pós-graduação em Ecologia de Ambientes Aquáticos \\ Continentais, Universidade Estadual de Maringá, Av. Colombo, 5790, Maringá, PR, \\ CEP 87020-900, Brazil, e-mail: bonecker@nupelia.uem.br \\ Received May 9, 2002 - Accepted July 11, 2002 - Distributed May 31, 2003
}

(With 1 figure)

\begin{abstract}
Rotifers present a high diversity in freshwater ecosystems. This study registered 11 genera and 42 species, new records for the Upper Paraná River floodplain. These results showed an increase in rotifer diversity in this ecosystem from 184 to 230 species. Among them some were registered only in the rivers and others in the lagoons. Thirty-seven species occurred in the littoral zone and 34 species in the pelagic; 3 species were registered only in the former zone and 2 species only in the latter. The lagoons presented the greatest richness, probably because of the greater stability, low current velocity, and the extensive aquatic macrophyte banks in the littoral zone of these environments as compared to those of the rivers. The highest number of species in the littoral habitats occurred due to the greater influence of shoreline vegetation, which allows greater habitat diversification. This fact contributed to the occurrence of non-planktonic species in the zooplankton samples.
\end{abstract}

Key words: rotifers, floodplain, richness, new records, Paraná river.

\section{RESUMO}

\section{Rotíferos da planície de inundação do alto rio Paraná: novas ocorrências}

Os rotíferos apresentam elevada diversidade em ambientes aquáticos continentais. Este estudo mostra novas ocorrências de 12 gêneros e 42 espécies desse grupo na planície de inundação do alto rio Paraná, o que incrementa o registro de 184 espécies para 230 espécies nesse ecossistema. Entre esses novos registros, algumas espécies ocorreram somente em lagoas e outras, apenas em rios. Foram encontradas 37 espécies na região litorânea e 34 na região pelágica dos ambientes estudados, dentre estas 3 espécies foram registradas apenas na primeira região e somente 2 na segunda região. As lagoas apresentaram os maiores valores de riqueza, provavelmente em razão da grande estabilidade, menor velocidade de corrente e presença de extensos bancos de macrófitas aquáticas. A presença de vegetação marginal permite grande diversificação de habitats, contribuindo para a ocorrência de um número expressivo de espécies na região litorânea. Esse fato contribuiu para a ocorrência de espécies não planctônicas no zooplâncton.

Palavras-chave: rotífero, planície de inundação, riqueza, novas ocorrências, rio Paraná. 


\section{INTRODUCTION}

Biodiversity is the variety of organisms considered at all levels and includes genetic and ecosystem variants, which comprise arrays of species, genera, and families, as well as communities of organisms within particular habitats and the physical conditions under which they live (Wilson, 1992).

Rotifers present a high diversity in freshwater ecosystems. According to Nogrady (1993), early rotifer distribution studies show that all rotifers are cosmopolitan, but recent research considers that endemism is significant in several genera, e.g., Notholca, and describes latitudinal zonation in certain planktonic rotifers and restricted distribution for some species (Green, 1972; Pjeler, 1977; Dumont, 1983).

The Paraná River segment discussed in this paper presents a wide braided channel with a low gradient $(0.09 \mathrm{~m} / \mathrm{km})$ and a wide floodplain in Mato Grosso do Sul State. This segment extends 480 $\mathrm{km}$ and may reach up to $20 \mathrm{~km}$ in width. It is the last non-dammed section of the Paraná River in Brazil (Agostinho et al., 1995).

New records from lagoons and rivers of the Upper Paraná River floodplain are included in this study following research developed by
Bonecker et al. (1994, 1998a), and Lansac-Tôha et al. (1997).

\section{MATERIAL AND METHODS}

Rotifers were collected at different depths from the littoral (surface) and pelagic (surface, middle, and bottom) regions in nine lagoons (Guaraná, $\mathrm{Au}-$ rélio, Fechada, Patos, Peroba, Cervo, Jacaré, Capivara, and Clara) and two rivers (Baía and Ivinheima) in the floodplain (Fig. 1). The samples were preserved immediately with buffered $4 \%$ formalin. Identification was based on Koste (1978), Koste \& Robertson (1983), José de Paggi (1989), Nogrady (1993), and Segers (1995).

\section{RESULTS}

A total of 11 genera (Kellicotia, Aspelta, Paradicranophorus, Encentrum, Lancinularia, Limnias, Sinantherina, Octotrocha, Lindia, Itura, and Tetrasyphons) and 42 species are new records for the Upper Paraná River floodplain (Table 1).

According to families, the greatest species richness increase was observed for Lecanidae ( 8 species), Brachionidae (6 species), and Notommatidae (6 species) (Table 1).

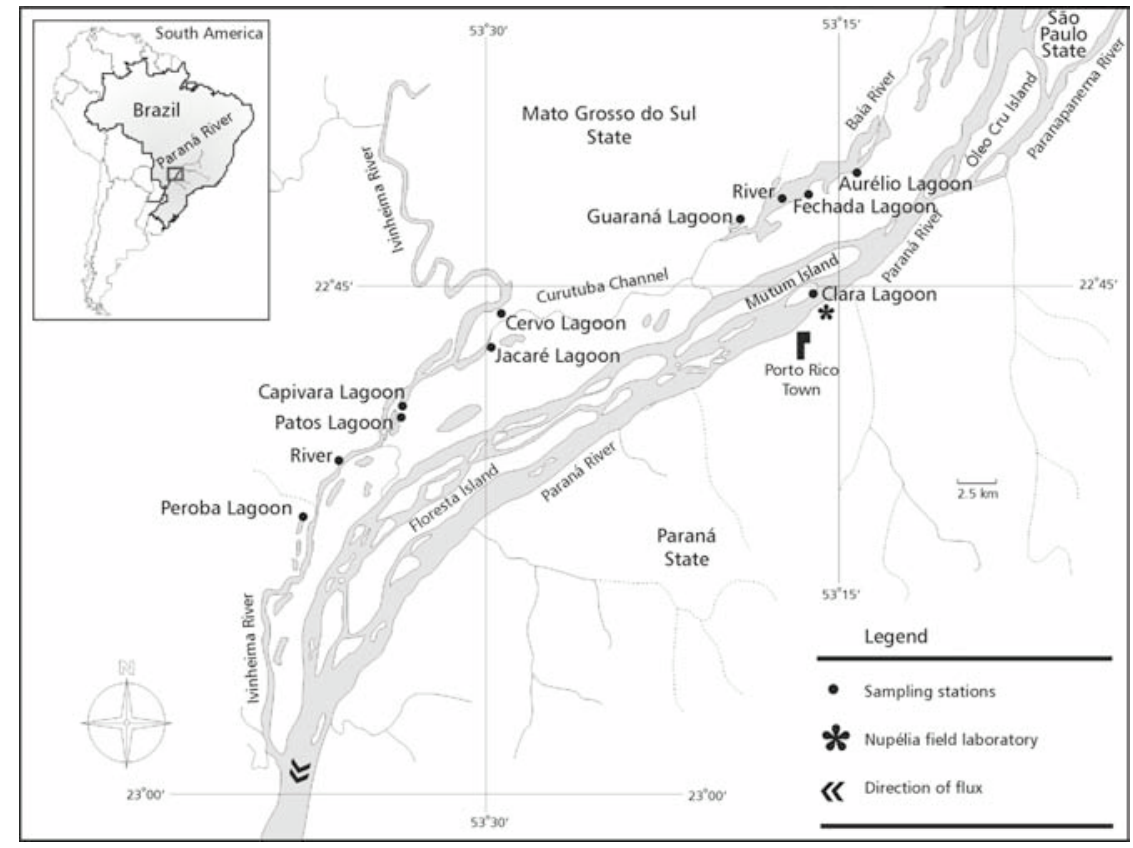

Fig. 1 - Study area and sampling stations. 
TABLE 1

Additional species of rotifers recorded in the different environments of the Upper Paraná River floodplain.

\begin{tabular}{|c|c|c|c|c|c|}
\hline \multirow{3}{*}{ Families } & \multirow{3}{*}{ Species } & \multicolumn{4}{|c|}{ Environments and habitats } \\
\hline & & \multicolumn{2}{|c|}{ River } & \multicolumn{2}{|c|}{ Lagoon } \\
\hline & & Littoral & Pelagic & Littoral & Pelagic \\
\hline \multirow[t]{6}{*}{ Brachionidae } & Brachionus caudatus austrogenitus Ahlstrom 1940 & & $\mathrm{X}$ & $\mathrm{X}$ & $\mathrm{X}$ \\
\hline & Brachionus caudatus insuetus Ahlstrom 1940 & $x$ & & $\mathrm{X}$ & $x$ \\
\hline & Brachionus forficula forficula Wierzejski, 1891 & & & & $\mathrm{x}$ \\
\hline & Brachionus mirus reductus (Koste, 1972) & $\mathrm{x}$ & $\mathrm{x}$ & $\mathrm{X}$ & $x$ \\
\hline & $\begin{array}{l}\text { Brachionus quadridentatus melheni (Barrois \& } \\
\text { Daday, 1894) }\end{array}$ & $x$ & & $x$ & $x$ \\
\hline & Kellicotia bostoniensis (Rousselet, 1908) & & & & $x$ \\
\hline \multirow[t]{4}{*}{ Trichocercidae } & Trichocerca macera (Gosse, 1886) & & & & $\mathrm{x}$ \\
\hline & Trichocerca longiseta (Schrank, 1802) & $\mathrm{x}$ & $\mathrm{x}$ & $\mathrm{x}$ & $\mathrm{x}$ \\
\hline & Trichocerca dixon nutalli Jennings, 1903 & & & & $\mathrm{x}$ \\
\hline & Trichocerca cf. tigris (O.F. Müller, 1786) & & & $\mathrm{X}$ & \\
\hline Epiphanidae & Epiphanes cf. macrourus (Barrois \& Daday, 1894) & & & & $x$ \\
\hline \multirow[t]{8}{*}{ Lecanidae } & Lecane bulla goniata (Harring \& Myers, 1926) & $\mathrm{x}$ & $\mathrm{x}$ & $\mathrm{x}$ & $\mathrm{x}$ \\
\hline & Lecane cornuta rotunda (Fadeew, 1927) & $\mathrm{x}$ & & $\mathrm{X}$ & \\
\hline & Lecane closterocerca wulferti (Hauer, 1956) & $x$ & & & \\
\hline & Lecane elegans Harring, 1914 & & $\mathrm{x}$ & & \\
\hline & Lecane ludiwigii ludiwigii (Eckstein, 1883) & $x$ & $x$ & & \\
\hline & Lecane ludiwigii ohiensis (Herrick, 1885) & $\mathrm{x}$ & $\mathrm{x}$ & & \\
\hline & Lecane unguitata (Fadeevi, 1925) & & & $\mathrm{X}$ & \\
\hline & Lecane hastata (Murray, 1913) & $\mathrm{x}$ & $\mathrm{x}$ & & \\
\hline Lindiidae & Lindia sp. & $x$ & & $\mathrm{x}$ & \\
\hline \multirow[t]{2}{*}{ Colurellidae } & Lepadella acuminata (Ehrenberg, 1834) & $x$ & $x$ & $\mathrm{x}$ & \\
\hline & Lepadella quinquecostata Lucks, 1912 & & & $\mathrm{x}$ & \\
\hline \multirow[t]{4}{*}{ Dicranophoridae } & Aspelta cf. angusta Harring \& Myers, 1928 & $x$ & $x$ & $\mathrm{X}$ & \\
\hline & Dicranophorus cf. robustus Harring \& Myers, 1928 & & & $\mathrm{x}$ & \\
\hline & Paradicranophorus wockei Koste, 1960 & & $\mathrm{x}$ & & \\
\hline & Encentrum sp. & $x$ & $x$ & $\mathrm{X}$ & \\
\hline Euchlanidae & Euchlanis Lyra (Myers, 1930) & $\mathrm{x}$ & & $\mathrm{x}$ & \\
\hline \multirow[t]{6}{*}{ Flosculariidae } & Lancinularia sp. & & & $\mathrm{x}$ & \\
\hline & Limnias sp. & & & $\mathrm{X}$ & \\
\hline & Pompholyx cf. triloba Pejler, 1957 & & $x$ & & $x$ \\
\hline & Sinantherina spinosa (Thorpe, 1893) & & $\mathrm{x}$ & $\mathrm{x}$ & \\
\hline & Sinantherina procera (Thorpe, 1889) & $x$ & $x$ & $\mathrm{x}$ & \\
\hline & Ptygura cf longicornis Donner, 1954 & & $\mathrm{x}$ & $\mathrm{X}$ & $\mathrm{x}$ \\
\hline \multirow[t]{2}{*}{\begin{tabular}{|l|} 
Gastropodidae \\
\end{tabular}} & Gastropus hyptopus Ehrenberg, 1938 & $\mathrm{x}$ & $\mathrm{x}$ & $\mathrm{X}$ & $x$ \\
\hline & Octotrocha sp. & & & $\mathrm{x}$ & $x$ \\
\hline Ituriidae & Itura sp. & $x$ & $x$ & $\mathrm{X}$ & $x$ \\
\hline \multirow[t]{3}{*}{ Mytilinidae } & Mytilinia ventralis macracantha (Gosse, 1886) & $\mathrm{x}$ & $\mathrm{x}$ & $\mathrm{X}$ & $\mathrm{x}$ \\
\hline & Mytilinia ventralis brevispinus Ehrenberg, 1832 & $x$ & $x$ & $\mathrm{X}$ & \\
\hline & Mytilinia cf. unguipes Lucks, 1912 & $\mathrm{x}$ & & & \\
\hline \multirow[t]{6}{*}{ Notommatidae } & Cephalodella forficula (Ehrenberg, 1838) & $\mathrm{x}$ & $\mathrm{x}$ & $\mathrm{x}$ & \\
\hline & Cephalodella gibba (Ehrenberg, 1838) & $\mathrm{x}$ & $\mathrm{x}$ & $\mathrm{X}$ & $\mathrm{x}$ \\
\hline & Cephalodella stenroosi Wulfert, 1937 & $\mathrm{x}$ & & $\mathrm{X}$ & \\
\hline & Cephalodella tenuiseta Harring \& Myers, 1924 & $\mathrm{x}$ & & $\mathrm{X}$ & $\mathrm{x}$ \\
\hline & Monommata cf. longiseta (O.F. Müller, 1786) & & $\mathrm{x}$ & $\mathrm{X}$ & $x$ \\
\hline & Scaridium longicaudium (O.F. Müller, 1786) & & & $\mathrm{X}$ & $x$ \\
\hline Tetrasiphonidae & Tetrasyphons hydrocora Ehrenberg, 1840 & $\mathrm{x}$ & $\mathrm{X}$ & $\mathrm{x}$ & $\mathrm{x}$ \\
\hline
\end{tabular}


Most species, such as Brachionus caudatus austrogenitus, Brachionus caudatus insuetus, Brachionus quadridentatus melheni, Trichocerca longiseta, Lecane bulla goniata, Lecane cornuta rotunda, Lepadella acuminata, Aspelta cf. angusta, Sinantherina spinosa, Sinantherina procera, Gastropus hyptopus, Mytilinia ventralis macracantha, Mytilinia ventralis brevispinus, Cephalodella forficula, Cephalodella gibba, Cephalodella stenroosi, Cephalodella tenuiseta, Monommata cf. longiseta, Lindia sp., Itura sp., and Tetrasyphons hydrocora occurred in the Patos Lagoon and Ivinheima River. Brachionus mirus reductus occurred in Guaraná and Patos lagoons and the Ivinheima River. Euchlanis lyra was registered in Guaraná Lagoon and Baía River.

Others species occurred only in the lagoons: Brachionus forficula forficula (Jacaré, Capivara, and Fechada), Kellicotia bostoniensis (Aurélio and Jacaré), Trichocerca macera (Cervo and Peroba), Trichocerca dixon nutalli (Clara), and Trichocerca cf. tigris, Lecane unguitata, Lepadella quinquecostata, Octotrocha sp., Dicranophorus cf. robustus, Scaridium longicaudium, and Epiphanes cf. macrourus (Patos).

Finally, some species were registered only in the Ivinheima River: Lecane elegans, Lecane ludiwigii ohiensis, Lecane hastata, Paradicranophorus wockei, and Mytilinia cf. unguipes.

Based on the horizontal distribution in each environment, some differences were verified. Thirtyseven species occurred in the littoral zone and 34 species in the pelagic. Among these, 3 (Trichocerca cf. tigris, Lecane unguitata, Mytilinia $\mathrm{cf}$. unguipes) species were registered only in the former zone and 2 (Lecane elegans, Paradicranophorus cf. wockei) only in the latter (Table 1).

Comparing the environments, the lagoons presented the greatest richness, is probably owing to the greater stability and low current velocity of these environments compared to that of the rivers.

\section{DISCUSSION}

The richness results increased rotifer diversity in the Upper Paraná floodplain from 184 species (Bonecker et al., 1994; Lansac-Tôha et al., 1997; Bonecker et al., 1998a) to 230 species.

The higher diversity observed for the Lecanidae and Brachionidae families was also true for these families in the Pantanal Matogrossense
(States of Mato Grosso do Sul and Mato Grosso) (Turner \& da Silva, 1992; Bonecker et al., 1998b; Martínez et al., 2000), the floodplains of the Middle Paraná River (Argentine stretch) (José de Paggi, 1996), the Upper Paraná River (Brazilian stretch) (Sendacz, 1993), and the rivers Amazon (Robertson \& Hardy, 1984; Bozelli, 1992), Orinoco (Twombly \& Lewis Jr., 1987; Vásquez \& Rey, 1989), Upper Orthon (Bolívia, Barbosa et al., 1999), and the Niger (Nigeria, Segers et al., 1993). The greatest occurrence of species of the genus Lecane in tropical regions was also mentioned by Koste \& Shiel (1983), Bozelli (1992), Bonecker et al. (1994), Dussart et al. (1984), Dabés (1995), Koste (1999), Sharma \& Sharma (2001). This genus and Brachiouns were best represented in Southeast Asia (Segers, 2001).

As for some limnological characteristics of the environments in the various floodplain environments, the lagoons are shallow (1.5-5.0 m) and present lowest mean values for temperature, conductivity, and dissolved oxygen, and the highest mean chlorophyll-a concentrations (Thomaz et al., 1992). They also have extensive banks of aquatic macrophytes in the littoral region, principally Eichhornia azurea (Schwartz) Kunth. These lowland lagoons occupy depressions formed by active or inactive channels, and have constant or intermittent communication with the Paraná River or secondary channels (Souza Filho \& Stevaux, 1997).

The rivers also present aquatic macrophytes in the littoral area, chiefly Eichhornia azurea (Schwartz) Kunth. The Baía River is characterized by low current velocity $(0.11-0.50 \mathrm{~m} / \mathrm{s})$ and high concentration of dissolved humic substances. The Ivinheima River has neutral to alkaline $\mathrm{pH}$, high conductivity, complete alkalinity, dissolved oxygen, and low chlorophyll-a concentrations (Thomaz et al., 1991; Bonecker \& Lansac-Tôha, 1996).

Although there is no great difference in rotifer richness between the habitats of these environments, the highest number of species in the littoral habitats occurred due to the greater influence of shoreline vegetation, which allows greater habitat diversification (Green, 1972). This fact contributed to non-planktonic species occurrence in the zooplankton samples (Bonecker et al., 1998a). The important role of emergent and submerged aquatic macrophytes in the community composition of rotifers was also verified in small lagoons and temporary ponds in the Pantanal Matogrossense (Bonecker et al., 1998b), in an artificial lake (Martínez et al., 2000) in the 
State of Mato Grosso do Sul, and in a New Zealand lake (Duggan et al., 1998).

The higher diversity observed in the lagoons was related to some characteristics of these environments, e.g., low velocity of current. According to Ward (1994), the reproducing populations of planktonic organisms are restricted to the slow-flowing lower reaches of these environments.

Acknowledgments - We thank CNPq, CAPES, and Nupélia for financial and logistical support. Dr. John Jervis Stanley Junior revised the english text.

\section{REFERENCES}

AgOSTINHO, A. A., VAZZOLER, A. E. A. M. \& THOMAZ S. M., 1995, The high River Paraná Basin: limnological and ichtyological aspects. In: J. G. Tundisi, C. E. M. Bicudo \& T. Matsumura-Tundisi (eds.), Limnology in Brazil. ACB/SBL, Rio de Janeiro, pp. 59-103.

BARBOSA, F. A. R., VILLART, F., SERRUDO, J. F. G., RENAULT, G. P. C. P., MAIA-BARBOSA, P. M., MENÉNDEZ, R. M., PEREIRA, M. C. F. \& VIANNA, J. A., 1999, Water quality, zooplankton and macroinvertebrates of the rio Tahuamanu and the rio Nareuda. In: B. Chernoff \& P. H. Willink (eds.), A biological assessment of the aquatic ecosystems of the Upper Rio Orthon basin, Pando, Bolivia. Conservation International (Bulletin of Biological Assessment), 15: 27-34.

BONECKER, C. C., LANSAC-TÔHA, F. A. \& STAUB, A., 1994, Qualitative study of rotifers in different environments of the High Paraná River flooplain (MS), Brazil. Rev. Unimar 16: $1-16$.

BONECKER, C. C. \& LANSAC-TÔHA, F. A., 1996, Community structure of rotifers in two environments of the high Parana River floodplain (MS), Brazil. Hydrobiologia, 325: 137-150.

BONECKER, C. C., LANSAC-TÔHA, F. A. \& BINI, L. M., 1998b, Composition of zooplankton in different environments of the Mato Grosso Pantanal, Mato Grosso, Brazil. In: Seminário Regional de São Carlos. PPG-ERN-UFSCar, pp. 1123-1135.

BONECKER, C. C., LANSAC-TÔHA., F. A. \& ROSSA, D. C., 1998a, Planktonic and non-planktonic rotifers in two environments of the Upper Paraná River floodplain, State of Mato Grosso do Sul, Brazil. Brazilian Archives of Biology and Technology, 41(4): 447-456

BOZELLI, R. L., 1992, Composition of the zooplankton community of Batata and Mussurá lakes and of the Trombetas River, State of Pará, Brasil. Amazoniana, 12: 239-261.

DABÉS, M. B. G. S., 1995, Composição e descrição do zooplâncton de 5 (cinco) lagoas marginais do rio São Francisco, Pirapora, Três Marias, Minas Gerais, Brasil. Rev. Bras. Biol., 55: 831-845.

DUGGAN, I. C., GREEN, J. D., THOMPSON, K. \& SHIEL, R. J., 1998, Rotifers in relation to littoral ecotone structure in Lake Rotomanuka, North Island, New Zealand. Hydrobiologia, 387/388: 179-197.
DUMONT, H. J., 1983, Biogeography of rotifers. Hydrobiologia, 104: 19-30.

DUSSART, B. H., FERNANDO, C. H., MATSUMURATUNDISI, T. \& SHIEL, R. J., 1984, A review of systematics, distribution and ecology of tropical freshwater zooplankton. Hydrobiologia, 113: 77-91.

GREEN, J., 1972, Freshwater ecology in the Mato Grosso, Central Brazil. III. Associations of Rotifera in meander lakes of the Rio Suiá Missú. J. Nat. Hist., 6: 229-241.

JOSÉ DE PAGGI, S., 1989, Rotíferos de algunas provincias del noroeste argentino. Rev. Hydrobiol. Trop., 22: 223-238.

JOSÉ DE PAGGI, S., 1996, Rotifera (Monogononta) diversity in subtropical waters of Argentina. Annls. Limnol., 32: 209220

KOSTE, W., 1978, Rotatoria Die Rodertiere Mitteleuropas begründet von Max Voigt - Monogononta. 2. Auflage neubearbeitet von Walter Koste. Gebrüder Borntraeger, 1: 238 .

KOSTE, W., 1999, Uber Radertiere (Rotifera) aus Gewassern des sudlichen Pantanal (Brasilien). Osnabrucker Naturwissenschaftliche Mitteilungen, 25: 179-209.

KOSTE, W. \& ROBERTSON, B., 1983, Taxonomic studies of the Rotifera (Phylum Aschelminthes) from a Central Amazonian varzea lake, Lago Camaleão (Ilha de Marchantaria, Rio Solimões, Amazonas, Brazil). Amazoniana, 8: 225-254.

KOSTE, W. \& SHIEL, R. J., 1983, Rotifer communities of Billabongs in northern and south-eastern Australia. Hydrobiologia, 104: 49-56.

LANSAC-TÔHA, F. A., BONECKER, C. C., VELHO, L. F. M., \& LIMA, A. F., 1997, Comunidade zooplanctônica. In: A. E. A. M. Vazzoler, A. A. Agostinho \& N. S. Hahn (eds.), A planície de inundação do alto rio Paraná: aspectos físicos, químicos, biológicos e socioeconômicos. Editora da Universidade Estadual de Maringá, Maringá, pp. 117-155.

MARTÍNEZ, J. C., CANESIN, A. \& BONECKER, C. C., 2000, Species composition of rotifers in different habitats of an artificial lake, Mato Grosso do Sul State, Brazil. Acta Scientiarium, 22(2): 343-346.

NOGRADY, T., 1993, Rotifera: biology, ecology and sistematics. The Hauge. SPB Academic Publishing, 1: 142

PJELER, B., 1977, On the global distribution of the family Brachionidae (Rotatoria). Arch. Hydrobiol., 53: 255-306.

ROBERTSON, B. A. \& HARDY, E. R., 1984, Zooplankton of Amazonian lakes and rivers. In: H. Sioli (ed.), The Amazon: limnology and landscape. Dr. W. Junk Publishers, pp. 337352. (Monographie Biologicae; 56).

SEGERS, H., NWADIARO, C. S. \& DUMONT, H. J., 1993 , Rotifera of some lakes in the floodplain of the River Niger (Imo State, Nigeria). Hydrobiologia, 250: 63-79.

SEGERS, H., 1995, Rotifera. The Lecanidae (Monogononta). Guides to the identification of the microinvertebrates of the continental waters of the world. SPB Academics, 2: 226.

SEGERS, H., 2001, Zoogeography of the Southeast Asian Rotifera. Hydrobiologia, 446/447: 233-246. 
SENDACZ, S., 1993, Distribuição geográfica de alguns organismos zooplanctônicos na América do Sul. Acta Limnologica Brasiliensia, 6: 31-41.

SHARMA, B. K. \& SHARMA, S., 2001, Biodiversity of Rotifera in some tropical floodplain lakes of the Brahmaputra River basin, Assam (N.E. India). Hydrobiologia, 446/447: 305-313.

SOUZA FILHO, E. E. \& STEVAUX, J. C., 1997, Geologia e geomorfologia do complexo rio Baía, Curutuba, Ivinheima. In: A. E. A. M. Vazzoler, A. A. Agostinho \& N. S. Hahn (eds.), A planície de inundação do alto rio Paraná: aspectos físicos, químicos, biológicos e socioeconômicos. Editora da Universidade Estadual de Maringá, Maringá, pp. 3-46.

THOMAZ, S. M., ROBERTO, M. C., LANSAC-TÔHA, F. A., ESTEVES, F. A. \& LIMA, A. F., 1991, Dinâmica temporal dos principais fatores limnológicos do rio Baía-planície de inundação do alto rio Paraná-MS, Brasil. Rev. Unimar, 13(2): 299-312.

THOMAZ, S. M., LANSAC-TÔHA, F. A., ROBERTO, M. C. ESTEVES, F. A. \& LIMA, A. F., 1992, Seasonal variation of some limnological factors of lagoa do Guaraná, a várzea lake of the high Paraná river, State of Mato Grosso do Sul, Brazil. Rev. Hydrobiol. Trop., 25(4): 269-276.
TURNER, P. N. \& DA SILVA, C., 1992, Littoral rotifers from the State of Mato Grosso, Brazil. Stud. Neotrop. Fauna Environ., 27: 227-241.

TWOMBLY, S. \& LEWIS-JR, W. M., 1987, Zooplankton abundance and species composition in laguna la Osinera, a Venezuela floodplain lake. Arch. Hidrobiol., 79: 87-107.

VÁSQUEZ, E. \& REY, J., 1989, A longitudional study of zooplankton along the lower Orinoco River and its Delta (Venezuela). Annls. Limnol., 28: 3-18.

WARD, J. V., 1994, The structure and dynamics of lotic ecosystems. In: R. Margalef (ed.), Limnology now: a paradigm of planetary problems. Elsevier Science B.V., pp. 195-218.

WILSON, E. O., 1992, The diversity of life. Allen Lane. The Penguin Press, London, 434p. 